\title{
The political ecology of local environmental narratives: power, knowledge, and mountain caribou conservation
}

\author{
R. Patrick Bixler ${ }^{1}$ \\ Colorado State University, USA
}

\section{Introduction}

The decline of the arboreal lichen feeding ecotype of woodland caribou known scientifically as Rangifer tarandus caribou (hereafter referred to as mountain caribou) in southeastern British Columbia is one of the most rigorously documented examples of the negative effect of anthropogenic disturbances on the dynamics of an endangered species (Wittmer et al. 2010; Siep 2008; Siep et al. 2007; Apps and McLellan 2006; Kotai 2006). Since the early 1980s, over 550 individual caribou have been captured and fitted with VHF telemetry or GPS collars, roughly one-third of the approximately 1,600 remaining individuals. Researchers have determined mountain caribou habitat requirements at multiple spatial scales (e.g., Apps et al. 2001), estimated age-specific vital rates including survival, and determined population sizes and trends (Wittmer et al. 2005). Available data have been used to develop a mechanistic understanding of the ultimate causes of observed population decline and there is broad consensus among most researchers that the decline of mountain caribou is due to unsustainable predation in the form of apparent competition (Wittmer et al. 2005; Wittmer et al. 2007; Festa-Bianchet et al. 2011).

In British Columbia, apparent competition has been largely linked to increases in moose and deer numbers following the loss of old-growth forest, predominantly through logging. Based on this science, researchers have contributed to the development of recovery strategies for mountain caribou across their remaining distribution. Recommendations usually involve protecting the remaining habitat from logging, implementing predator control (either lethal or non-lethal) as well as control of alternate prey species (achieved mostly by increasing hunting quotas). Since mountain caribou are at an immediate risk of population extinction (highlighted by the extirpation of two of the initial eighteen remaining populations in 2004; Wittmer et al. 2005; Wittmer et al. 2010), there has been some urgency to move from conservation science to conservation action. However, implementation of mountain caribou conservation strategic action plans is dependent on the cooperation of local stakeholders that are embedded in the landscape and have competing political and economic interests. Despite the well-researched and communicated science, mountain caribou populations continue to decline.

The case of mountain caribou illustrates the political ecology of local environmental narratives. The science and ecology of the mountain caribou provides a cohesive narrative, yet local stakeholders construct alternatives to explain the decline, and they position these narratives within contested political and ecological contexts. Experts (and their associated expertise) are not self-evident. Neither is the power they enact (or fail to enact) to move from conservation science and knowledge to action and practice. In this article I will draw on a more diffuse and discursive notion of power to discuss the ways that local stakeholders talk about mountain caribou decline and link those narratives to the 'historical regularities' of the roles and positions of those telling the narrative. Historical regularities condition and constrain the actual use or exercise of our minds across a series of practices, that are at once material and institutional. They govern the ways that we talk about environmental issues and the ways we delimit 'rational' knowledge and action. The mountain caribou narratives are deeply embedded in particular economic, political, and ideological constructions and situated in local practices. I explore these themes through a discursive narrative analysis of local stakeholders. The analysis of these narratives reveals the alternating perceptions of the problem and reveals factures between different interest groups. The focus on narratives of caribou decline and their implicit solutions provides an interesting critique of the science-policy interface and problematizes the way that these intimate local views could be reconciled into conservation action and practice. The argument builds a nuanced critique of the rationality of local ecological knowledge by posing questions about the politics and the forms of power on which it rests.

\footnotetext{
${ }^{1}$ R.Patrick Bixler, PhD student, Department of Sociology, Colorado State University, Fort Collins, CO 80523-1784, USA. Email: Patrick.Bixler "at" colostate.edu. Thankyou to two referees and the editors.
} 


\section{Literature review: political ecology and the politics of science and local knowledge}

The integration of local ecological knowledge and traditional scientific knowledge regarding ecosystem dynamics is an increasingly popular topic within the environmental management literature. Recent discussions of social-ecological systems (Berkes and Folke 2003), polycentric governance (Bixler in press; Ostrom 2010), co-management (Berkes 2009), and community-based natural resource management (Larson and Soto 2008) illustrate the importance of this objective. The justification for engaging local people and their knowledge in resource governance is simple: any intervention that is inattentive to historical and geographical specificities, local conditions, and local knowledge will likely fail.

Under the lens of political ecology, the broader social and political context of scientific knowledge creation is ripe for critical analysis. Pielke notes the importance of understanding the "complex interface of science and decision making in which science is 'co-produced' by various sectors of society, and separation of 'facts' and 'values' cannot be achieved" (Pielke 2004: 407). The ways in which human societies establish and maintain boundaries between scientific and other forms of authority - legal, political, religious, and social are important considerations (Jasanoff 1999). Gieryn (1999) illustrates that drawing boundaries around social groups and biophysical entities - and the interactions at specific temporal and spatial scales - is a process that frames 'legitimate' science and policy. When policy prescriptions assume that the boundaries between the scientific, technological, and social are given and unchangeable, a premature narrowing in both the framing and solution of perceived problems can occur. Jasanoff notes;

Scientific knowledge, in particular, is not a transcendent mirror of reality. It both embeds and is embedded in social practices, identities, norms, conventions, discourses, instruments, and institutions - in short, in all the building blocks of what we term the social... (2004: 3, emphasis in original).

This is particularly salient for political ecology, where social and economic practices are taken to shape the ecosystem dynamics under scientific investigation, and conservation policy prescriptions often aim to restrict those situated practices deemed problematic. Political ecology, and its loosely knit body of research, provides a useful framework that focuses attention on;

(1) the role of the local resource user and the capabilities and "decision-making environment" that affect the ways that resources are used;

(2) the ways that local resource use is shaped by social and economic relations at multiple scales;

(3) the ways that historical processes have shaped and continue to shape these relations;

(4) the ways that society and the 'natural' or human-modified physical environment mutually shape each other over time (Walker 1998). This is what Blaikie and Brookfield (1997) call "the shifting dialectic between...social groups and their physical environment."

Increasing sensitivity to these dynamics has led scholars and practitioners to recognize how stakeholders are embedded in their political and ecological context and how this shapes knowledge of ecosystem dynamics (Berkes 2003; Carolan 2010; Chapin et al. 2009; Raymond 2010). Social embeddedness is a source of considerable ambivalence about how people think about (and act towards) the world around us, and;

...roles, structural / cultural expectations, obligations, ideology, and the like all have the potential to pull us indifferent - and sometimes contradictory - directions. (Carolan 2010: 312)

A source of this ambivalence come from disconnect between an objective, disembodied 'Science' and embodied local knowledge. Actors are engaged in the world - embodied in their world - in a world full of subjective, situated and normative meaning. This world of relations is in contrast, at the very least epistemologically, from the world of science. "Science," notes Jasanoff, "wrenches phenomena out of their specific contexts, makes parts meaningful independently of wholes, and recombines segments in ways that transgress boundaries..." (2010: 235). Scientific knowledge focuses on relationships, variables, and phenomena that are usually invariant. To do so effectively, the production of science tends to erase specificity and transcend the subjective and contingent circumstances of the local. In this way, 'facts' may float freely and carry legitimacy through objectivity (Latour 1990).

As Oreskes (2004) notes, producing logically indisputable proofs about the natural world (that meet these criteria) is inherently problematic. One response to these challenges is the increasing recognition and validity of local ecological knowledge. Local Ecological Knowledge (LEK) is defined as knowledge, 
practices, and beliefs regarding ecological relationships that are gained through extensive personal observation of and interaction with local ecosystems, and shared among local resource users (Charnley et al. 2008). Local ecological knowledge refers to the local expertise of people who, different from indigenous peoples, may not have a long-term relationship (i.e. hundreds or thousands of years) with the local environment, but nevertheless have local wisdom, experience, and practices adapted to local ecosystems (Ballard et al. 2008). This knowledge is held by users of a resource system and is informal, lay, personal and often implicit or tacit, but also can often be considered expert (Raymond et al. 2010; Carolan 2006). Notably absent in discussions of local ecological knowledge, however, is the role of narrative. Environmental narratives are the;

...stories that are bounded by narrator's particular experiences, observations, and attachment to place. They include anecdotal information, oral environmental history, local knowledge, and are analogous to traditional indigenous knowledge. (Robertson et al. 2000: 120)

A more nuanced understanding is warranted of local environmental narratives, local ecological knowledge, and political ecology at the interface of conservation science and policy (Vaccaro et al. 2013).

\section{Method and analytical approach}

The empirical basis for this paper is ethnographic field work conducted in Revelstoke, British Columbia during the summer of 2007 (Figure 1). The study used two interrelated data collection methods: participant observation and semi-structured interviews (Lofland, et al. 2006). I began my interview sample by contacting public officials involved with the Revelstoke Community Forest. I conducted fifteen in-depth interviews, among four main stakeholder groups: forestry (5 interviewees), recreation and tourism (4) ${ }^{2}$, environmental interests (4), and public officials (3). Table 1 summarizes the characteristics of the participants.

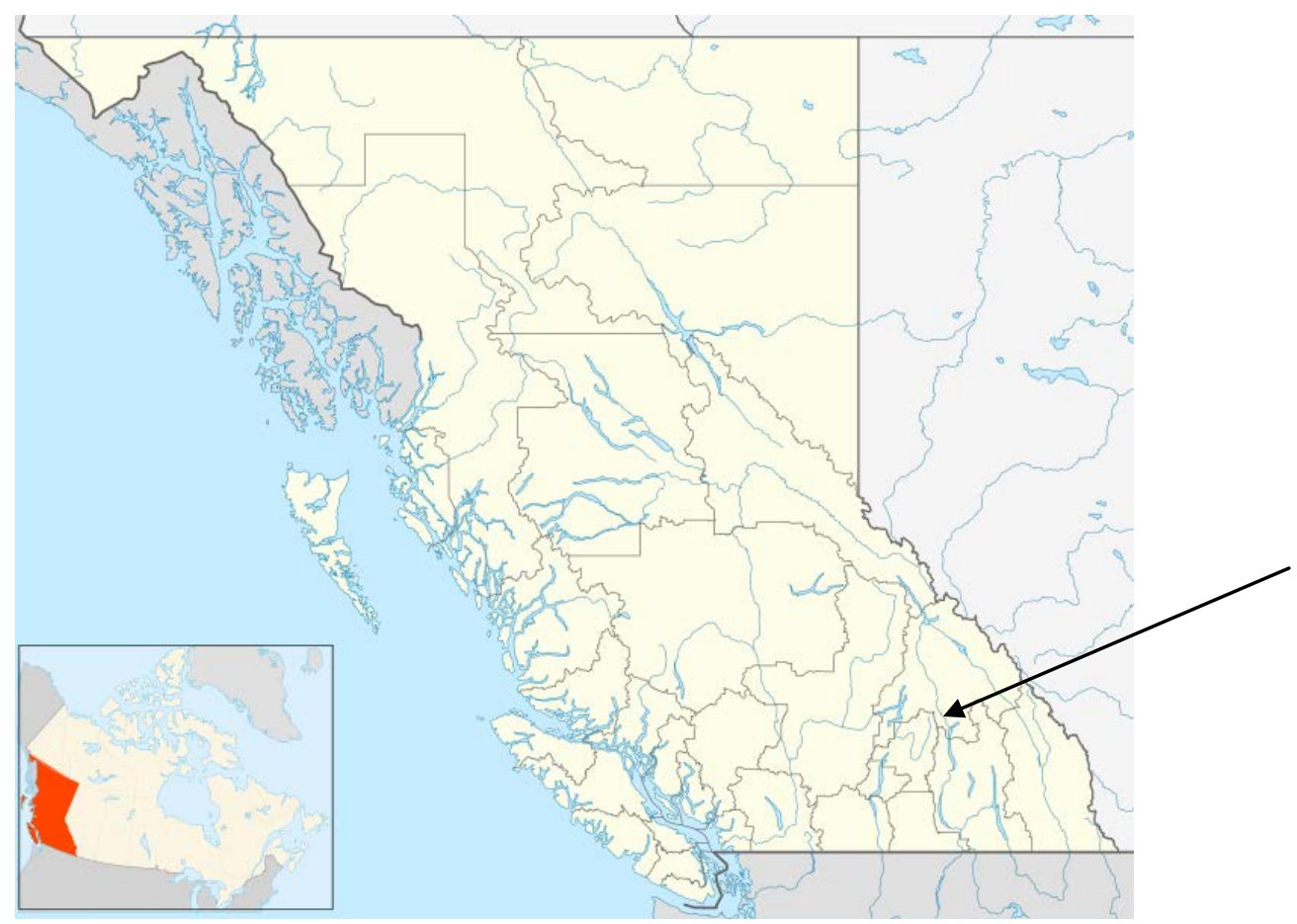

Figure 1: Revelstoke, British Columbia, Canada. Source: Wikipedia.

\footnotetext{
${ }^{2}$ One participant I classified in both the forestry and recreation and tourism stakeholder groups.
} 
Participants ranged from those involved in a local community forest, to the heli-ski industry, and park biologists and local environmental NGOs. I used a purposive snowball technique in which participants were asked to provide me with names of others with valuable perspectives (Bryman2004). This brought me into contact with key decision-makers, community leaders, and a range of natives (born and raised), neo-natives ( $>15$ years of residence), and new-comers ( $<15$ years of residence). An interview guide was used to ensure consistency across participants; however, they were also encouraged to talk about topics of interest to them. The interviews were fully tape-recorded and transcribed verbatim to permit detailed coding (Strauss and Corbin 1998). The data was analyzed using QSR N6 (NVivo) software. Analysis of the emerging concepts was done through coding and recoding of the data, and unifying themes emerged (Charmaz 2006). A second set of codes was used to further investigate emerging relationships and to describe underlying issues (Strauss and Corbin 1998). The participant observation included many hours of informal activities and conversations with local residents and tourists visiting Revelstoke. These informal interactions and the activities provide a valuable social context for interpreting the content of the interviews, as well as additional data in the form of field notes. I also gathered and analyzed documentary materials from the area, especially signs and pamphlets describing snowmobile closures due to mountain caribou habitat and literature provide by the provincial government regarding the mountain caribou. Triangulation of multiple sources of data helps increase its validity (Yin 2003).

\begin{tabular}{|c|c|c|c|c|c|c|c|}
\hline Participant & Gender & $\frac{\text { Stakeholder }}{\text { group }}$ & $\begin{array}{l}\text { Resident } \\
\text { status }\end{array}$ & Participant & Gender & $\frac{\text { Stakeholder }}{\text { group }}$ & $\begin{array}{l}\text { Resident } \\
\text { status }\end{array}$ \\
\hline$\# 1$ & Male & Tourism \& Rec. & $\begin{array}{l}\text { Neo- } \\
\text { Native }\end{array}$ & $\# 9$ & Male & Forestry & Native \\
\hline \#2 & Male & Public Official & Native & $\# 10$ & Male & Forestry & Native \\
\hline \#3 & Female & Environmental & Native & \#11 & Female & Environmental & Newcomer \\
\hline \#4 & Male & Forestry & Native & $\# 12$ & Male & Public Official & Native \\
\hline \#5 & Female & $\begin{array}{l}\text { Forestry / Tourism } \\
\text { \& Rec. }\end{array}$ & $\begin{array}{l}\text { Neo- } \\
\text { Native }\end{array}$ & $\# 13$ & Male & Forestry & Native \\
\hline$\# 6$ & Female & Tourism \& Rec. & Native & $\# 14$ & Male & Public Official & $\begin{array}{l}\text { Neo- } \\
\text { Native }\end{array}$ \\
\hline \#7 & Male & Environmental & Newcomer & $\# 15$ & Male & $\begin{array}{l}\text { Tourism \& } \\
\text { Rec. }\end{array}$ & Native \\
\hline$\# 8$ & Male & Environmental & $\begin{array}{l}\text { Neo- } \\
\text { Native }\end{array}$ & & & & \\
\hline
\end{tabular}

Table 1: Interviewee characteristics.

The analysis of the data was grounded in narrative and discourse analysis, which focuses on "the constructed and constructive nature of language" (Shotter and Gergen 1989: 207) in relation to the social context in which it is used. The social context includes the practices and subjectivities that shape perceptions of environmental change. This calls attention to the stories that are told about environmental issues, highlighting the embeddedness of environmental issues in broader power relations, histories, and contextual issues (Fischer 2003). Narratives are a relational explanation for the way embodied actors in an environment make sense of the world, constituting a psychological, social, and linguistic framework often worked out through social interaction (Gergen 1994).

A focus on narratives also reveals how science is used to translate things into an authoritative knowledge that is disembedded, and reveals important social and cultural dimensions of the environment and environmental problems. Analyzing narratives from diverse stakeholders allows the piecing together of storylines that imply causality, and can often be linked to larger global environmental discourses (e.g. Adger et al. 2001). Analysis of narratives illustrates a more nuanced account of the interconnections and interactions between the scientific and the social, the economic and the political.

It is important to note that the narrative analysis is filtered through a critical realist lens. A critical realist perspective acknowledges that knowledge-producing actions can make sense only when the assumption of the existence of an independent material reality is granted (Benton 2001). Yet critical realism acknowledges that there is a distinction between the way things are and our knowledge claims about those objects of knowledge (Carolan 2005). As Jasanoff states, "if our field [science and technology studies] is to regain the significance it was once thought to hold for public policy, it will need, first and foremost, to get rid of the label 'deconstruction"' (1999: 65). Therefore, the results presented below do not seek to deconstruct the science of Rangifer tarandus caribou but rather present narratives of mountain caribou situated in historical regularities of political and economic context. 


\section{Results: framing mountain caribou decline}

\section{The context}

Like many rural towns in interior British Columbia, mining, transportation (by railroad) and the timber industry have been the basis of many livelihoods in Revelstoke since the late 1880s. In 1965, the building of three hydroelectric dams in the area stimulated the local economy with construction jobs and created large reservoirs of fresh water. The boom induced by these mega-projects only lasted a few decades and flooded vast expanses of prime forest. Following a social and economic low point in the mid-1980s, the municipality of Revelstoke acquired community forest tenure from the provincial government. Since that time the timber industry has been a relatively stable driver of the local economy. In the last decade, tourism has significantly contributed to the local economic base. The Revelstoke Mountain Ski Resort ${ }^{3}$, an active and motorized winter recreation industry in the surrounding Columbia Mountains (including both heli-skiing and snowmobiling), Mt. Revelstoke National Park, and a regional Parks Canada office provide for tourismbased livelihoods for a number of local residents.

These economic and political contexts shape the local narratives of mountain caribou. Few residents, and none that that were officially interviewed, would deny the mountain caribou population is declining. One research participant, a forestry stakeholder, recalled monitoring caribou populations in the community forest area in 1976. ${ }^{4}$ "You know in the last decade, it's been noticeable that the caribou populations are declining and that's a community value to preserve caribou." However, agreement about population decline was not found in the narratives used to explain it. Even when elements of storylines are shared (i.e. agreement over mountain caribou population decline), the attribution of those stories and the meanings attached to the stories can still differ (Hajer 1995). Participants in the study used four principle narratives to talk about mountain caribou: 'fragmented habitat', 'motorized recreation', 'predation', and 'climate change.' While some participants recognized that multiple factors could be at play, most participants privileged the discourse of one narrative over the others.

\section{Fragmented habitat}

Of the four narratives, fragmented habitat is the most exhaustive explanation of mountain caribou decline. The underlying argument is that the reduction of core habitat by logging and past hydroelectric energy development has negatively affected the herds. A forest manager draws on this narrative when he says "we may have to reduce our cutting in order to avoid converting more of their habitat to second growth forest." Most residents agree that fragmented habitat has reduced the mountain caribou's chances for survival, although logging is not the only driver of forest fragmentation for them, and narratives generally align in suggesting that forest fragmentation is a consequence of damming the upper Columbia River. A biologist notes, "the problem with caribou right now is, I think, that we've lost the valley bottoms where all the predators and prey happily hung out together." And a local forester adds: "well, there is an old legacy of hydro-dams that kind-of screwed things up. It would have been nice if that had occurred a little differently or hadn't happened at all." Two elements of this narrative - logging and dam building - have drastically different conservation actions associated with remedying them. The dams were something that "kind-of screwed things up," whereas the logging is an on-going practice. Consequently, any conservation efforts that aim to mediate fragmented habitat can only address the logging component of this narrative.

This broader narrative of fragmented habitat was supported by a diverse set of stakeholders, however timber production is contested as a driver more than the effects of dams on landscape fragmentation. In general, this narrative links to larger environmental discourses that blame fragmented habitat for species loss. A local heli-ski operator uses this narrative when he talks of scientists providing authoritative knowledge;

It is pretty well established by the biologist that their [mountain caribou] habitat has been fragmented by such a large degree now that they don't have the range, the freedom to range, as they did before and access to their food sources.

The policy implications of fragmented habitat are that individual (woodlot), community (community forestry), and industrial logging in the area should be limited. This was also the finding of a scientific study in the late 2000s that said 2.2 million hectares should be protected from logging and road building in order to protect mountain caribou habitat (B.C. Ministry of Agriculture and Lands 2007).

This is not the only narrative people in Revelstoke tell about the plight of the mountain caribou. When I asked a forest scientist in the area, who has studied their habitat in the region, if poor forest practices

\footnotetext{
${ }^{3}$ http://www.revelstokemountainresort.com

${ }^{4}$ At the time the area was technically known as TFL 23 and was owned by Celgar Ltd.
} 
were to blame for the declining population, the response was; "no, I think its $30 \%$ dams and $70 \%$ forestry, but they are related. The cut went up to log the reservoirs and they never brought it down." Then I asked about a second narrative, the impacts of motorized recreation, and the response was "Oh yeah! You'd have to put that on top of that too. The percentages wouldn't add up."

\section{Mechanized recreation}

The mountain caribou have an interesting behavioral trait that leads to increased human-wildlife interaction. In late winter as the snowpack deepens, they move from lower to higher elevations to feed on lichen that hangs from trees. While this is well documented in mountain caribou, this is not common behavior in other ungulate species. During this migration to the alpine, mountain caribou often encounter other high country winter users - mechanized recreationists. The underlying argument of this narrative is that the stress caused by mechanized recreation, mainly snowmobiles and helicopters (for heli-skiing), is the root cause of their decline. One resident involved in the timber products industry talks about this impact;

Hikers like you and I, we can leave a light footprint, but some guy riding around on a snowmobile and climbing the mountain, that has an impact. Like heli-skiing...This thing is swooping into a valley and there is a herd of caribou there, you can't tell me that doesn't have some impact or provide some stress to the caribou, it provides stress to me!

Another resident, in the forestry stakeholder group, speaks hopefully about the benefits restriction to mechanized winter recreation would have on the mountain caribou populations;

You'll see some significant restrictions on some of the motorized recreation. And hopefully, with all of that the caribou will rebound and will have some stability in their population.

Locally, the impacts of heli-skiing and snowmobiling were discussed equally. But the scientific focus has been primarily on the effects of snowmobiles, to the exclusion of the impacts of helicopters. The politically contested and contentious nature of this narrative was evident when I was warned against asking questions related to mechanized recreation and caribou, and snowmobile stakeholders repeatedly did not respond to my requests to set up interview dates or outright declined to speak with me. The narrative of mechanized recreation was widely used to explain impacts on the mountain caribou populations, although less supported as a stand-alone root cause of the declining populations.

\section{Predation}

Fragmented habitat and mechanized recreation are two narratives that residents in Revelstoke talk about as the root cause of mountain caribou decline. The following statement from a native environmental stakeholder sums up the two previous narratives and introduces the third one, predation;

So the combination of all those activities: flooding the valley bottom, logging which is a big part of it, and motorized recreation including backcountry and heli-skiing and the fact that those activities have been operating in the middle and upper slopes where the caribou live too. Much easier access by man, much easier access by predators: cougars, wolves; um, hey, it's changed the whole opportunity for caribou to remain. I mean they get stressed and their population has been in decline.

Often, predation is talked about as supplementing one of the first two narratives. Due to snowmobile tracks or because of logging roads, the mountain caribou are more vulnerable to predators than in the past. A heli-ski industry employee make this assumption, "got wolves in there, we're convinced wolves came in on snowmobile tracks and wiped them out or chased them out." And likewise, because of forestry activity predation occurs;

But as soon as they started opening up the valleys with the clear cuts, cleaning everything out, the deer came in...And what followed them of course were the cougars and the wolves, because the food source moved there and caribou are a lot easier for a cougar to take down or a wolf to take down than a moose. So, the fragmentation of the habitat and the predators that came in... 
Participants from diverse stakeholder groups discussed predation as a primary cause of caribou decline. The narrative is salient in Revelstoke because if it is the cause, then social practices in the forest can continue as usual. A Parks Canada employee contends;

So they [the Revelstoke Community Forest Corporation] supported a letter that went in asking for predator killing, which is so archaic. But yet there are people in town that are now believing the wolves are eating the caribou, they are not. Actually, they are being eaten by five species of predators of which wolves are the least.

This comment from the environmental stakeholder group talks about the official municipal support for this narrative, which aptly illustrates its political, social, and economic dimensions. Certain narratives may be politically and economically expedient, in that if predation is the root cause, then logging and motorized recreation can continue in the forest.

\section{Climate change}

The final narrative that people talk about in Revelstoke as a root cause for caribou decline is climate change. Climate change is often talked about as a root cause, in addition to just accepting the idea that "it's a species shift";

If we look to the mountain caribou as a moment in geological time of planetary change and it's a species shift that is going to happen because of what has happened elsewhere.... you know this is happening because of climate change and its happening because of past logging and even if you were to stop logging up here and do whatever we could to recover caribou, we can't, we practically cant, so we are not going to bear the costs on both sides of the sustainability balance sheet because we aren't going to have benefits on the other side.

The implications of this narrative are similar to predation. If climate change is problematized as the root cause, social practices in the forest can continue unabated. Because of climate change, the mountain caribou are declining and therefore responsibility and agency for taking conservation action is absolved. The mountain caribou population is declining for reasons that go beyond the capabilities of local action. Similarly, climate change and its effect on the interior wet belt ecosystem came up in many contexts: one resident said; "I'm still not convinced of that given climate change, we may just be throwing out the jobs for really no benefits. But I can't get the wildlife guys to look at the damn climate change stuff." This recognizes the complexity of social-ecological systems, and subsequently similar statements were used by a diverse range of stakeholder interests.

\section{Discussion: narratives as knowledge and political ecology}

Environmental narratives, such as those explaining mountain caribou decline, can be analytically useful in understanding the particular framings of 'nature' and the social embeddedness of particular actors. The narratives point towards the general constraints of the human knowing process and the tendency to impose static categories on the natural world, simplifying the complexity of feedback loops integral to socialecological systems. Narratives are crafted by social ideologies and used to legitimate particular economic activities, to distort scientific-empirical understanding, and to inform a stakeholder experience of the forest. The positionality of stakeholders within a historical and ecological context connects the material foundations of their experience in the landscape to ideological positions. Moreover, the narratives that stakeholders tell reflect the historical regularities of their position, leading to assumptions about attribution and causality. Table 2 describes five characteristics for each of the four narratives.

Within a narrative are actions that are being promoted or implicitly authorized to address the root cause of mountain caribou decline, and further, an attribution of blame. The positionality of the narrator plays an important role in these aspects of narrative construction, as indicated by a forestry stakeholder: "and they'll [heli-skiers] tell you that the caribou just stand there and look at them." Likewise, a local recreation and tourism employee recalls other stakeholder's stories as they draw on embodied experience;

We don't affect the caribou at all, we can sled right up to them and they'll just sit there and watch. They don't do anything until we get off our sleds...so they say, well, we're not affecting the caribou. ["standard line from the sledders"] 
Caribou, we're not affecting the caribou, shit [sic] the caribou come right in we drive up to the cut block and there is caribou all over the place eating the lichen, hell we're feeding the caribou. ["the standard line for the loggers"]

The employee goes further to explain how he sees his own practices affecting, or rather not affecting, the mountain caribou;

These caribou grew up with us. They know that that big helicopter going by does not present any danger at all. In contrast, a little helicopter is what biologist use to net them, tag them and when a little helicopter comes into the area they are up and gone...

\begin{tabular}{|c|c|c|c|c|c|}
\hline & \multicolumn{5}{|c|}{ Narratives of mountain caribou decline } \\
\hline & Attribution & Causality & $\begin{array}{l}\text { Positioned } \\
\text { observer }\end{array}$ & Legitimacy & $\begin{array}{l}\text { Implied } \\
\text { action }\end{array}$ \\
\hline $\begin{array}{l}\text { Habitat } \\
\text { fragmentation } \\
\text { (dams) }\end{array}$ & The State & $\begin{array}{l}\text { Flooding } \\
\text { Columbia River } \\
\text { valley bottom }\end{array}$ & Local residents & $\begin{array}{l}\text { Historical } \\
\text { assumptions about } \\
\text { pre-dam } \\
\text { ecosystem } \\
\text { dynamics }\end{array}$ & $\begin{array}{l}\text { Dam } \\
\text { removal }\end{array}$ \\
\hline $\begin{array}{l}\text { Habitat } \\
\text { fragmentation } \\
\text { (timber) }\end{array}$ & $\begin{array}{l}\text { Owners of 'Tree } \\
\text { Farm License' } \\
\text { tenure (woodlot, } \\
\text { community, } \\
\text { industry) }\end{array}$ & $\begin{array}{l}\text { Forestry practices } \\
\text { fragmenting forest } \\
\text { habitat (cut blocks, } \\
\text { clear cuts) }\end{array}$ & $\begin{array}{l}\text { Motorized } \\
\text { recreation users } \\
\text { whom 'see' } \\
\text { fragmented } \\
\text { habitat; scientists }\end{array}$ & $\begin{array}{l}\text { Embodied } \\
\text { experience; } \\
\text { forestry science }\end{array}$ & $\begin{array}{l}\text { Reduced } \\
\text { annual } \\
\text { allowable } \\
\text { cut }\end{array}$ \\
\hline $\begin{array}{l}\text { Motorized } \\
\text { recreation }\end{array}$ & $\begin{array}{l}\text { Recreationists and } \\
\text { tourism operators / } \\
\text { businesses }\end{array}$ & $\begin{array}{l}\text { Displacement by } \\
\text { snowmobiles and } \\
\text { helicopters }\end{array}$ & $\begin{array}{l}\text { Mechanized } \\
\text { recreationists and } \\
\text { operators }\end{array}$ & $\begin{array}{l}\text { Conservation } \\
\text { biology }\end{array}$ & $\begin{array}{l}\text { Restricted } \\
\text { access }\end{array}$ \\
\hline Predation & $\begin{array}{l}\text { Prey / Predator } \\
\text { dynamics }\end{array}$ & $\begin{array}{l}\text { Human induced } \\
\text { (roads, tracks); } \\
\text { natural factors }\end{array}$ & Scientists & $\begin{array}{l}\text { Conservation } \\
\text { biology }\end{array}$ & $\begin{array}{l}\text { Predator } \\
\text { removal }\end{array}$ \\
\hline Climate change & $\begin{array}{l}\text { Earth system } \\
\text { dynamics }\end{array}$ & $\begin{array}{l}\text { Changing climate } \\
\text { and landscape } \\
\text { scale structure and } \\
\text { function }\end{array}$ & Local residents & $\begin{array}{l}\text { Climate science } \\
\text { 'speculated' to } \\
\text { create local scale } \\
\text { interactions }\end{array}$ & No action \\
\hline
\end{tabular}

Table 2: Narratives of mountain caribou decline

Elements of these narratives can be easily correlated with direct, personal experiences, independent of any relation to scientific knowledge. The process that links these experiences in a material landscape to a larger ideological structure rationalizes narratives as pseudo-legitimate ecological knowledge (legitimate, at the very least, to that stakeholder group). Understanding local narratives, whether or not they are 'true', is therefore critical for conditioning local responses and mitigation strategies for species conservation and landscape-scale ecosystem management. These narratives, however, don't gain validity without being contextualized. Rather, the narratives clearly align with political and economic interests of the stakeholder group. If the social identification was with the timber industry, the narrative the interviewees drew upon was almost exclusively in line with those interests. If the participant was from the tourism and recreation stakeholder group, again, the same could be expected. This finding is not that surprising, as studies into the sociology of knowledge have identified these dynamics for many years. Karl Mannheim (1936) wrote about the connection between the constructs of thoughts and social structure. He was making the connection between 'perspectives' and social groups: "he speaks the language of his group; he thinks in the manner in which his group thinks" (Mannheim 1936: 3). From the perspective of the sociology of knowledge, we expect that individuals will tend to favour a narrative that is in accord with how they identify socially.

Nonetheless, the situation is more nuanced than this, and simple claims reduce the complexity of the deeper conditions to which principal ecological facts are subordinated. Stakeholders are positioned in political, economic, and ecological contexts with histories that produce both structural and directional regularities for that group. Projections of these historical regularities are illustrated in the narratives where 
they move from attribution and causality to implying certain conservation actions (Table 2). Stakeholders that would be most affected if habitat fragmentation was established as the cause of mountain caribou decline have a history of economic activity in timber production and its associated booms and busts. Moreover, these stakeholders have power in this discursive arena due to the economic stability that accrues from community forest tenure and management (regarding the Revelstoke Community Forest, see Bixler in press). Consequently, power and resources are mobilized to legitimate other narratives.

Certain narratives explicitly display attempts to maintain the boundaries between different forms of power and authority. The narrative of predation clearly separates the scientific (in which evidence supports habitat fragmentation and motorized recreation), from the political (the Revelstoke municipality as well as the provincial government of British Columbia have issued statements supporting the removal of predators wolves - for mountain caribou conservation) and from the economic (predation implies little or no regulation on forestry or motorized recreation). Any attempt to establish this narrative as the root cause of caribou decline implies some degree of boundary maintenance (Gieryn 1999).

Additionally, the mechanized recreation narrative highlights the contrast between 'objective science' and situated and embodied knowledge. Previous research has shown how local knowledges are not always separable from expert, state, or scientific knowledge (Agrawal 1995, Robbins 2000), and it is not surprising that some forest users draw from the narrative of mechanized recreation to explain mountain caribou decline from experience rather than science. Increasingly it is emphasized that embodied experience and knowledge is important and more than just representational, as Carolan puts it, "our beliefs about nature are intimately tied to our acts and practices. They are shaped, in a word, by our doings" (original emphasis, 2008: 5). When a heli-ski operator has an interaction with a caribou and the caribou "know that the big helicopter going by does not present any danger" these beliefs about nature are intimately tied to their practices. This is not local ecological knowledge in the more traditional sense but rather knowledge that is positional and historical and in relation to broader contours of power.

Despite all forest user narratives converging with the story line that mountain caribou are declining, where the narratives diverge is critical because adopted action is going to infringe upon someone's vested interests. Diverse narratives of change often agree with scientific assessments of threats to regional sustainability (Harris 2009), yet when science moves from questions of what is, to policy questions of what should be done then public sentiments and values, in addition to scientific knowledge, must be incorporated. A strict focus on local ecological knowledge as it is usually framed - as environmental knowledge about resources and natural processes - does not necessarily incorporate 'public sentiments and values.' By constructing local narratives of environmental change we can see the subjectivities and positions from which the narratives emerge and the ways power is used to legitimate particular knowledges.

\section{Conclusion: environmental narratives as local ecological knowledge}

Many scholars have called for greater inclusion of local knowledge in resource management and development planning (e.g. Berkes and Folke 1998; Cash et al. 2003; Ostrom 1990; Raymond et al. 2010). This is complimentary to others who have challenged the appropriateness of abstract, technical or bureaucratic knowledge (Scott 1998). Indeed, in the face of complex environmental threats many scholars have made the push for the democratization of science and expertise (Beck 1992; Carolan 2006). Yet, the interest in narratives is distinct from efforts to validate the veracity of one claim over another as with many attempts to demonstrate the suitability of indigenous knowledge as preferential to abstracted state and scientific knowledge.

Knowledge has been defined as a mix of experiences, values, contextual information, and intuition that provides a framework with which to evaluate and incorporate new experiences and information (Davenport and Prusak 1997). In this sense, narratives about mountain caribou decline certainly constitute local ecological knowledge. Understanding these narratives and how they are constructed from historical regularities and social interaction, and how they enact power through discourse, is crucial to a conservation policy that successfully engages local peoples to achieve ecological outcomes. Exploring the subjectivities of local knowledge claims illustrates how narratives of environmental change are similar to, although different from, the rationality usually assumed for local ecological knowledge.

Environmental sociologists argue that many of the socio-biophysical effects of modernity are beyond direct perception, that these effects are 'epistemologically distant' - beyond the level of the empirical but nevertheless real (Beck 1992; Carolan 2004). The epistemological perspective is different to local ecological knowledge that informs migratory bird management, for example (see Gilchrist et al. 2005). Whereas the trend in studies of local ecological knowledge is to illustrate the empirically valid 'truths of nature' (although from a contextualized perspective), a focus on environmental narratives reminds us of the importance of the subjectivities and ideologies of individuals, as they understand complex social-ecological interactions. 
Any conceptual project to integrate local ecological knowledge into conservation science and policy must also be predicated on a parallel project to understand the political ecology of how and why that knowledge is being framed as it is. A political ecology of local environmental narratives brings power to the foreground. The social and ecological processes the forest users believe are responsible for mountain caribou decline is a product of complex power relationships between scientists, policy-makers, other forest users, and local and global economic structures. Alternative narratives navigate political, economic, and ecological contexts and empower some stakeholders while constraining others. The process that turns those narratives to policy to practice can either produce a resistant, uncooperative stakeholder or one more conducive to working collaboratively for mountain caribou conservation. The most exact and instructive mountain caribou conservation science is only informative to the degree that forest users find salience within their social ideology, which in turn emerges from their material practices in the landscape. An empathy for these discursive positions is necessary to link conservation science and practice, and can be used to better understand the attitudes and actions of people in relation to the more diffuse threats associated with global environmental changes.

\section{References}

Adger, W.N., T.A. Benjaminsen, K. Brown, and H. Svarstad. 2001. Advancing a political ecology of global environmental discourse. Development and Change, 32: 681-715.

Agrawal, A. 1995. Dismantling the divide between indigenous and scientific knowledge. Development and Change 26: 413-439.

Apps, C. D., B. N. McLellan, T. A. Kinley, and J. P. Flaa. 2001. Scale-dependent habitat selection by mountain caribou, Columbia Mountains, British Columbia. Journal of Wildlife Management 65: 65-77.

Apps, C. D. and B. N. McLellan. 2006. Factors influencing the dispersion and fragmentation of endangered Mountain Caribou populations. Biological Conservation 130: 84-97.

B.C. Ministry of Agriculture and Lands. 2007. Mountain Caribou recovery actions. Backgrounder: 2007AL0050-001308.

Beck, U. 1992. Risk society: toward a new modernity. London: Sage.

Benton, T. 2001. Environmental sociology: controversy and continuity. Sosiologisk Tidsskrift, 9: 5-48.

Berkes, F. 2009. Evolution of co-management: role of knowledge generation, bridging organizations and social learning. Journal of Environmental Management 90: 1692-1702.

Berkes, F., and C. Folke (eds.). 1998. Linking sociological and ecological systems: management practices and social mechanisms for building resilience. Cambridge: Cambridge University Press.

Berkes, F., J. Colding, and C. Folke (eds.). 2003. Navigating social-ecological systems: building resilience for complexity and change. Cambridge: Cambridge University Press.

Bixler, R.P. In press. From community forest management to polycentric governance: assessing evidence from the bottom-up. Society and Natural Resources.

Blaikie, P. and H.C. Brookfield 1987. Land degradation and society. New York and London: Methuen.

Bryman, A. 2004. Social research methods. $2^{\text {nd }}$ ed. Oxford: Oxford University Press.

Carolan, M.S. 2004. Ontological politics: mapping a complex environmental problem. Environmental Values 13: 497-522.

Carolan, M.S. 2005. Realism without reductionism: toward an ecologically embedded sociology. Human Ecology Review 12: 1-20.

Carolan, M.S. 2006. Science, expertise, and the democratization of the decision-making process. Society and Natural Resources 19: 661-668.

Carolan, M.S. 2008. More-than-representational knowledge/s of the countryside: how we think as bodies. Sociologia Ruralis 48: 408-422.

Carolan, M.S. 2010. Sociological ambivalence and climate change. Local Environment 15 (4): 309-321.

Cash, D.W., W.C. Clark, F. Alcock, N.M. Dickson, N. Eckley, D.H. Guston, J. Jager, and R.B. Mitchell. 2003. Knowledge systems for sustainable development. Proceedings of the National Academy of Sciences 100 (14): 8086-8091.

Charmaz, K. 2006. Constructing grounded theory: a practical guide through qualitative analysis. Thousand Oaks: Sage Publications.

Chapin, F.S., G. P. Kofinas, and C. Folke (eds.). 2009. Principles of ecosystem stewardship. New York: Springer Science. 
Charnley, S., A.P. Fischer, and E.T. Jones. 2008. Traditional and local ecological knowledge about forest biodiversity in the Pacific Northwest. Gen.Tech. Rep. PNW-GTR-751. Portland: U.S. Department of Agriculture \& Forest Service, Pacific Northwest Research Station.

Davenport, T.H. and L. Prusak. 1997. Working knowledge: how organizations manage what they know. Boston: Harvard Business School Press.

Festa-Bianchet, M., J.C. Ray, S. Boutin S, S.D. Cote, A Gunn. 2011. Conservation of caribou (Rangifer tarandus) in Canada: an uncertain future. Canadian Journal of Zoology 89(5): 419-434

Fischer, F. 2003. Reframing public policy: discursive politics and deliberative practices. Oxford University Press. Review

Funtowicz, S.O. and J.R. Ravetz. 1993. Science for a post-normal age. Futures 25:739-755.

Gergen, K. 1994. Toward transformation in social knowledge. London: Sage.

Gieryn, T. 1999. The cultural boundaries of science. Chicago: University of Chicago Press.

Gilchrist, H.G., M.L. Mallory, and F. Merkel. 2005. Can local ecological knowledge contribute to wildlife management? Case studies of migratory birds. Ecology and Society 10 (1): 20.

Harris, L. M. 2009. Contested sustainabilities: assessing narratives of environmental change in Southeastern Turkey. Local Environment 14 (8): 699-720.

Hajer, M.A. 1995. The politics of environmental discourse: ecological modernization and the policy process. Oxford: Clarendon Press.

Jasanoff, S. 1999. The songlines of risk. Environmental Values 8:135-152.

Jasanoff, S. (ed). 2004. The co-production of science and social order. London: Routledge.

Kotai, J. 2006. Mechanized use in BC's protected areas. In J. Shutlis (ed.) Selected issues facing BC parks: report to the BC protected areas research forum. University of Northern British Columbia. Pp. 7988.

Latour, B. 1990. Visualization and cognition: drawing things together. In M. Lynch and S. Woolgar (eds.) Representation as scientific practice. Cambridge MA: MIT Press. Pp. 19-68.

Larson, A.M. and F.Soto. 2008. Decentralization of natural resource regimes. Annual Review of Environment and Resources 33: 213-239.

Lofland, J., D. Snow, L. Anderson and L. H. Lofland. 2006. Analyzing social settings: a guide to qualitative observation and analysis. $4^{\text {th }}$ Edition. Belmont, CA: Wadsworth.

Mannheim, K. 1936. Ideology and utopia: an introduction to the sociology of knowledge. San Diego: Harcourt Inc.

McGinnis, M.D. 1999. Polycentric governance and development: readings from the workshop in political theory and policy analysis. Ann Arbor: University of Michigan Press.

Oreskes, N. 2004. Science and public policy: what's proof got to do with it? Environmental Science and Policy 7: 369-383.

Ostrom, E. 1990. Governing the commons: evolution of institutions for collective action. Cambridge: Cambridge University Press.

Ostrom, E. 2010. Polycentric systems for coping with collective action and global environmental change. Global Environmental Change 20: 550-557.

Pielke, R. A. Jr. 2004. When scientists politicize science: making sense of controversy over The Skeptical Environmentalist. Environmental Science and Policy 7: 405-417.

Raymond, C.M., I. Fazey, M.S. Reed, L.C. Stringer, G.M. Robinson, A.C. Evely. 2010. Integrating local and scientific knowledge for environmental management. Journal of Environmental Management 91: 1766-1777.

Robbins, P. 2000. The practical politics of knowledge: state environmental knowledge and local political economy. Economic Geography 76 (2): 126-144.

Robertson, M., P. Nichols, P. Horwitz, K. Bradby and D. MacKintosh. 2000. Environmental narratives and the need for multiple perspectives to restore degraded landscapes in Australia. Ecosystem Health 6 (2): 119-133.

Roth, W-M. J. Riecken, L. Pozzer-Ardenghi, R. McMillan, B. Storr, D. Tait, G. Bradshaw, and T.P. Penner. 2004. Those who get hurt aren't always being heard: scientist-resident interactions over community water. Science, Technology, and Human Values 29: 153-183.

Sarewitz, D. 2004. How science makes environmental controversies worse. Environmental Science and Policy 7: 385-403.

Scott, J. 1998. Seeing like a state: how certain schemes to improve the human condition have failed. New Haven: Yale University Press. 
Siep, D.R., C.J. Johnson and G.S. Watts. 2007. Displacement of mountain Caribou from winter habitat from snowmobiles. Journal of Wildlife Management 71(5): 1539-1544. Draft

Siep, D. R. 2008. Mountain Caribou interactions with wolves and moose in central British Columbia. ALCES, 44:1-5.

Shotter, J. and K. Gergen (eds.). 1989. Texts of identity. London: Sage.

Strauss, A. and J. Corbin. 1998. Basics of qualitative research: grounded theory procedures and techniques. London: Sage.

Vaccaro, I., O. Beltran and P.A. Paquet. 2013. Political ecology and conservation policies: some theoretical genealogies. Journal of Political Ecology 20: 255-272.

Walker, P. 1998. Politics of nature: an overview of political ecology. Capitalism, Nature, Socialism 9 (1): 131-144.

Weinberg, A. 1972. Science and trans-science. Minerva 10: 209-222.

Wittmer, H.U., R.N.M. Ahrens, and B.N. McLellan. 2010. Viability of Mountain Caribou in British Columbia, Canada: effects of habitat change and population density. Biological Conservation 143: 86-93.

Wittmer H.U., B.N. McLellan, D. R. Seip, J.A. Young, T.A. Kinley, G.S. Watts and D. Hamilton. 2005. Population dynamics of the endangered mountain ecotype of woodland caribou (Rangifer tarandus caribou) in British Columbia, Canada. Canadian Journal of Zoology 83(3): 407-418.

Wittmer H.U., B.N. McLellan, R.Serrouya, and C.D. Apps. 2007. Changes in landscape composition influence the decline of a threatened woodland Caribou population. Journal of Animal Ecology 76: 568-579.

Yin, R. K. 2003. Case study research, design, and methods. Newbury Park: Sage.

\begin{abstract}
Political ecology seeks to address notable weaknesses in the social sciences that consider how human society and the environment shape each other over time. Considering questions of ideology and scientific discourse, power and knowledge, and issues of conservation and environmental history, political ecology offers an alternative to technocratic approaches to policy prescriptions and environmental assessment. Integrating these insights into the science-policy interface is crucial for discerning and articulating the role of local resource users in environmental conservation. This paper applies political ecology to addresses a gap in the literature that exists at the interface of narratives of local environmental change and local ecological knowledge and doing so builds a nuanced critique of the rationality of local ecological knowledge. The ways that we view nature and generate, interpret, communicate, and understand the "science" of environmental problems is deeply embedded in particular economic, political, and ecological contexts. In interior British Columbia, Canada, these dynamics unfold in one of the most rigorously documented examples of the negative effect of anthropogenic disturbance on an endangered species - declining mountain caribou population. Science notwithstanding, resource users tell narratives of population decline that clearly reflect historical regularities deeply embedded in particular economic, political, and ideological constructions situated in local practices. This research assesses these narratives, discusses the implications, and explores pathways for integrating local knowledge and narratives into conservation science and policy. A more informed understanding of the subjectivities and rationalities of local knowledges can and should inform conservation science and policy.
\end{abstract}

Keywords: Political ecology, local ecological knowledge, narrative, environmental change, environmental management, British Columbia, Rangifer tarandus caribou. 


\section{Résumé}

L'écologie politique cherche à combler les lacunes dans les sciences sociales qui portent sur la façon dont la société humaine et la forme de l'environnement de l'autre au fil du temps. L'écologie politique offre une alternative aux approches technocratiques aux prescriptions de la politique et de l'évaluation environnementale. Il examine les questions d'idéologie et discours scientifique, la puissance et la connaissance, et les enjeux de la conservation et de l'histoire de l'environnement. L'intégration de ces connaissances dans l'interface science-politique est essentiel pour discerner et articuler le rôle des utilisateurs des ressources locales dans la préservation de l'environnement. Cet article s'applique écologie politique pour combler les lacunes observées dans la littérature qui existe à l'interface des récits de changement de l'environnement local et les connaissances écologiques locales et ce faisant crée une critique nuancée de la rationalité des savoirs écologiques locaux. Les moyens que nous considérons la nature et de générer, d'interpréter, communiquer et comprendre la «science» des problèmes environnementaux sont profondément ancrées dans des contextes économiques, politiques et écologiques. En intérieur de la Colombie-Britannique, au Canada, ces dynamiques se déroulent dans l'un des exemples les plus rigoureusement documentés de l'effet négatif des perturbations anthropiques sur une espèce en voie de disparition - déclin de la population de caribous de montagne. Sciences nonobstant, les utilisateurs des ressources racontent des histoires de déclin de la population qui reflètent les régularités historiques profondément enracinées en particulier les constructions économiques, politiques et idéologiques situés dans les pratiques locales. Cet article évalue ces récits, discute de leurs implications, et explore des voies d'intégration des connaissances et des récits locaux dans la science et la politique de conservation. Une compréhension plus éclairée des subjectivités et des rationalités des savoirs locaux peut et doit informer la science et la politique de conservation.

Mots-clés: Écologie politique, les connaissances écologiques locales, les récits, les changements environnementaux, la gestion environnementale, la Colombie-Britannique, Rangifer tarandus caribou.

\section{Resumen}

La ecología política tiene por objeto abordar las notables deficiencias existentes en las ciencias sociales que se encargan de entender cómo la sociedad humana y el medio ambiente se moldean mutuamente a lo largo del tiempo. Teniendo en cuenta las diferentes ideologías y el discurso científico, el poder y el conocimiento, y las cuestiones de conservación y la historia del medio ambiente, la ecología política ofrece una alternativa a los enfoques tecnocráticos sobre propuestas de políticas y evaluación ambiental. La integración de estos conocimientos entre ciencia y política es fundamental para discernir y articular el papel de los usuarios de recursos locales en la conservación medioambiental. Este documento aplica la ecología política para abordar el vacío existente en la literatura al unir la narrativa de los cambios ambientales locales con el conocimiento ecológico local para de esta manera construir una crítica sutil a la racionalidad del conocimiento ecológico local. La forma en que vemos a la naturaleza para generar, interpretar, comunicar y comprender la "ciencia" de los problemas medioambientales está profundamente arraigada a los particulares contextos económicos, políticos y ecológicos. En el interior de Columbia Británica, Canadá, estas dinámicas muestran uno de los ejemplos más rigurosamente documentados de los efectos negativos que han tenido la perturbación antropogénica sobre una especie en peligro de extinción - la disminución de la población del caribú de la montaña. A pesar de la ciencia, los usuarios de recursos narran sobre la disminución de la población que reflejan claramente las regularidades históricas profundamente arraigadas en prácticas locales de su particular contexto económico, político e ideológico. Esta investigación evalúa estas narrativas, analiza las consecuencias y explora vías para la integración de conocimientos y narrativas locales en la ciencia de conservación y política. Una mejor y más informada comprensión de las subjetividades y racionalidades de los conocimientos locales pueden y deben informar a la ciencia política y de la conservación .

Palabras clave: ecología política, conocimiento ecológico local, la narrative, cambio ambiental, gestión ambiental, Columbia Británica, Rangifer tarandus caribou. 